\title{
Climbing to freedom on an impossible staircase: exploring the emancipatory potential of becoming an entrepreneur-employer
}

\author{
Helen C. Williams ${ }^{1}$, Katrina Pritchard ${ }^{1}$, Maggie C. Miller ${ }^{1}$ and Cara Reed ${ }^{2}$ \\ 1: School of Management, Swansea University, Bay Campus, Fabian Way, Swansea, \\ SA1 8EN. \\ 2: Cardiff Business School, Cardiff University, Aberconway Building, Colum Dr, \\ Cardiff CF10 3EU
}

Version accepted for publication in International Small Business Journal

Users who receive access to an article through a repository are reminded that the article

is protected by copyright. Users may download and save a local copy of an article

accessed in an institutional repository for the user's personal reference.

\section{All images provided are copyright $\odot$ Helen $C$ Williams, 2020; permission must be sought before images are reproduced.}

\section{Contact: k.l.pritchard@swansea.ac.uk}

\begin{abstract}
This article contributes to critical discussions questioning the emancipatory potential of entrepreneurship, through examining the experiences of men and women entrepreneurs who have recently become employers in South Wales, UK. Our research uses a co-creative visual method based in Interpretative Phenomenological Analysis (IPA) to explore transitions from entrepreneur to entrepreneur-employer in everyday contexts. Findings demonstrate how initial emancipatory experiences become increasingly bounded when becoming an entrepreneur-employer. This exposes a Catch-22 of entrepreneuring-asemancipation as a symptom of neoliberal entrepreneurial discourses that constrain what entrepreneurs are encouraged to do: grow. We find a plurality of particular emancipations, but conclude that within a developed context, entrepreneurship and more specifically, becoming an entrepreneur-employer is a relational step through which perceived constraints become more readily experienced and emancipation never fully realised.
\end{abstract}

Key Words: Entrepreneur, emancipation, neoliberalism, enterprise, IPA. 


\section{Introduction}

Contributing to a growing body of reflexive and critical research, we unpack the premise of entrepreneurship as emancipatory. Empirically, we extend the work of Verduijn et al. (2014) who reposition entrepreneuring using Laclau's (1996: 98) conceptualisation of emancipation 'as intimately related to oppression'. This article examines what extent this duality is experienced by entrepreneur-employers within a neoliberal system.

Within such a system, entrepreneurship is positioned as a solution to a wide variety of societal problems (Wiklund et al., 2019). There remains an implicit belief that more entrepreneurship is better (Marlow, 2020), and leads to both individual and societal social and economic growth (Fletcher and Seldon, 2016). Indeed, this assumption is reflected in policies encouraging individuals to start and grow an enterprise as a means to a 'potentially life-changing experience' (Department for Work and Pensions, 2020). In both the EU and the UK, entrepreneurial growth is measured by whether an enterprise has any employees beyond those who started it (Eurostat, 2020). However, despite encouragement, data suggests that individuals who start an enterprise are not likely to grow it (UK Business Population Estimates, 2019). Literatures identify the non-employer to employer transition as critical to whether an enterprise (and indeed, the entrepreneur) achieves growth or not (Coad et al., 2017; Caliendo et al., 2019). However empirical work examining what it is like to grow an enterprise and employ staff is predominately functionalist, with the role of the entrepreneur largely ignored (Tunberg and Anderson, 2020).

To better understand how fulfilling neoliberal ideals are lived out by those being encouraged directly to achieve it, this article draws on understandings of neoliberalism as a 'regime of subjectification' (Dean, 2014: 152). This is geared towards the production of subjects capable of realising economic and personal growth through becoming both an entrepreneur, and an employer. This transition has yet to be empirically explored within critical entrepreneurship literatures investigating the role and influence of neoliberalism.

In contrast to the extensive body of work that approaches neoliberalism as a governing apparatus, we suggest a need to understand the extent to which entrepreneurs themselves feel emancipated as they take the significant step of becoming an employer. This follows Gill and Scharff's (2013: 8) encouragement to consider how governing practices 'quite literally get inside us to materialise or constitute our subjectivities'. Taking 
this perspective demands focus into the 'psychic life' of neoliberalism to understand how it is lived out by entrepreneurs pursuing the neoliberal ideal of growth by becoming employers (Scharff, 2016; Bandinelli, 2020). This leads us to the phenomenological commitments of our study.

The investigation of lived experience is certainly not novel and the value of doing so is well documented, particularly in addressing epistemic gaps between theory and practice (Chia 2003; Nayak et al. 2020). Our phenomenological framework allows us to address this gap. Interpretative Phenomenological Analysis (IPA) provides a lens to examine how our worlds are subjectively distinct yet share characteristics that are common to us all (Eatough and Shaw, 2019). The use of participatory, visual and multimodal methods are becoming increasingly common in IPA (Boden et al., 2019) and entrepreneurship studies (Clarke and Holt, 2019; Van Burg et al., 2020). Following this trend, we used objects (in our case, Lego) as elicitation tools (Woodward, 2020) to enhance the phenomenological interview.

Furthermore, our research responds to calls to challenge the ideological foundations of entrepreneurship (Essers, et al., 2017). Research has been criticised for failing to unpack the ways in which ideologies rooted in neoliberalism and entrepreneurship interact (Ahl and Marlow, 2019; Baker and Welter, 2020). Neoliberalism positions entrepreneurship, and indeed being 'entrepreneurial' as a self-directed means to achieving emancipation (Mavelli, 2017). Various schools of thought converge to define emancipation as 'setting something free from control or restraint' or 'declaring someone as free' (Lindebaum, 2017: 2). Within the entrepreneurship literature, most definitions appear to still build on the Schumpeterian (1989) idea that the logics of capitalism, as propagated by Friedman (1962), and embodied by the entrepreneur. These logics are regarded as appropriate tools for achieving individual freedom (Fayolle and Matlay, 2010).

Capitalist logic is built on the assumption that economic freedom is causally related to political freedom (Forder, 2019; Pryor, 2010). This draws from Friedman's (1962) supposition that capitalism is a necessary, but not sufficient, condition for political freedom. With regard to freedom, Rothschild (2003) concludes that Friedman does not consider 'positive freedom,' which concerns opportunities, or the freedom to do something. Rather he focuses on constraints, and the idea that capitalism provides the conditions to provide the freedom from oppressive structures or societal obligations. Thus, 
entrepreneurship becomes embodied as not just a social or economic force but reconceptualised as an emancipatory activity (Goss et al., 2011; Jones and Murtola, 2012; Rindova et al., 2009; Weiskopf and Steyaert, 2009).

Contemporary neoliberal and entrepreneurial discourses unite in emphasising the right to make individual choices. This emphasis lends itself to an 'enterprise culture' (Rose, 1992: 13) that manifests subjectively through the enterprising self: work on yourself, be independent, emancipate your authentic self and realise your potential. This emancipated self is then free to choose to be anyone they want to be. Outcomes such as personal fulfilment and economic good become 'entwined' (Ahl and Marlow, 2019: 19), and appealingly tangible, rather than subjectively self-produced (Gill and Scharff, 2013; Scharff, 2016). Consequently, studies that have addressed emancipation empirically primarily focus on marginalised groups (i.e. migrants and women) in developing economic regions (Al-Dajani et al., 2015; Haugh and Talwar, 2016; Pergelova et al., 2017). Limited studies examining the broader application of entrepreneurship's emancipatory potential in everyday contexts suggesting that this perspective has become normalised, if not expected. Thus, a central question remains as to whether entrepreneurship is experienced as emancipatory (Verduijn et al., 2014), particularly when pursuing the neoliberal imperative of enterprise growth and thus moving to become an entrepreneur-employer.

This article unpacks the everyday potential for emancipation by studying female and male business founders who have recently transitioned from entrepreneur to entrepreneur-employer in South Wales, UK. Our findings reveal the transition to employer is experienced as a plurality of emancipations, fleetingly felt. We consider becoming an entrepreneur-employer as a relational step, where constraints become more readily experienced. As one of our participants reflected, it is like 'going up the stairs and falling back down', you 'never get to the top'. Consequently, the study seeks to address the following research question: to what extent do entrepreneurs experience emancipation when transitioning from entrepreneur to entrepreneur-employer?

The remainder of the article is structured as follows. Firstly, further conceptual insight into our positioning of neoliberalism and entrepreneurship is outlined before turning to consider dominant and critical approaches to emancipation. Secondly, a detailed explanation of the research approach is provided. Subsequently, findings are presented and then discussed with regards to their implications for research and practice. 


\section{Neoliberalism and Entrepreneurship}

Neoliberalism is central to scholarly debates and inquiries into contemporary functioning of power and socioeconomic inequality (Birch and Springer, 2019). Within this, notions of freedom are framed and used in a specific way: in terms of the 'autonomy' of the individual (Dardot and Laval, 2019). Entrepreneurial discourses embrace the idea of personal responsibility as a means to individual success. Individuals must buy into a very particular notion of entrepreneurial freedom in that they are responsible for achieving it (Cook, 2020). Neoliberalism capitalises autonomy as being, or aspiring to be entrepreneurial, in that individuals must 'own' everything that happens to them and thus continually self-regulate (Bröckling, 2016).

Autonomy here has a paradoxical quality (Börner et al., 2020), portrayed as a natural desire of all humans and not something that is given. However, neoliberalism is often positioned as a form of emancipation that is felt in all parts of our lives - public and private (Rose, 2017). With artificial constraints removed, the extent to which individuals realise this natural autonomy is limited only by the amount of time, effort or capital they are prepared to invest in achieving it. This shift of responsibility makes us all become seekers of something: self-determination, maximisation of our health (Cederström and Spicer, 2015), our bodies (Moor and Robinson, 2016; Pritchard et al., 2019), our work (Musílek et al., 2020) and our lifestyles through consumption. The 'unemployed become job seekers; refugees become asylum seekers' (Rose 2017: 4); tourists become thrill seekers; entrepreneurs become fortune seekers - it is from this perspective, never-ending.

One of the defining contradictions of neoliberalism is that it is packaged as concerned with individual freedom, choice, growth, democracy and personal responsibility, yet each of these concepts limits another from being truly realised (Dean, 2014). This points to an inherent contradiction that lies quietly at the heart of Laclau's (1996) concept of emancipation, and neoliberalism: that constraints exist and that we can be freed from them. Amongst a multiplicity of conceptual interpretations, Laclau's difficulty with the determinism that depicts emancipation is perhaps best realised as the achievement of freedom from a constraint within systemically neoliberal contexts; stemmed from countries such as the US or UK to a now global level (Fraser, 2017). This conceptualises emancipation as something that can be attained and sustained, as opposed to continually sought after. Sensibilities of a need to emancipate on an individual level are 
perhaps bounded by neoliberalism in various ways, and thus a pathology of the contemporary neoliberal subject. This can be particularly prescient for entrepreneurs who gain autonomy from an organisation by becoming their own employer, but who in turn become an employer of others in the pursuit of continued financial growth.

Public policy continues to reinforce the belief that becoming an entrepreneur is a means to achieve neoliberal ideals that entwine the potential for individual emancipation with wider social changes, like reducing unemployment rates (Mallett and Wapshott, 2020). The implicit assumption across much of this literature is that more entrepreneurship is better (Marlow, 2020). As the European Commission's (2020: 1) 'The Entrepreneurship Action Plan' declares: 'To bring Europe back to growth and create new jobs, we need more entrepreneurs.'

At a national level, the UK Government's 'New Enterprise Allowance', offers jobseekers a chance to receive a small government loan to start a business. Promotional material for this national scheme includes promise of a '...potentially life-changing experience. Moving forward from being on benefits to having the power to become your own boss, it's vital we do all we can to help fulfil your dreams' (Department for Work and Pensions, 2019). This emancipatory discourse reflects the all too familiar neoliberal rhetoric that frames entrepreneurship as a means for wealth and job creation, creativity, innovation and personal risk-taking (Matinez Dy et al., 2018).

It is also notable that many existing studies exploring the potential for entrepreneurship to be emancipatory predominantly focus on subsets of individuals who are arguably deemed the most in need of liberation. There remains an emphasis towards women in developing countries (Baker and Welter, 2017; Welter et al., 2019) or ethnic minorities (Jones and Ram, 2015), and marginalised women within more developed nations (Jennings et al., 2016; Al-Dajani et al., 2019). An implication of this focus is that the broader applicability of the emancipation perspective is still open to debate, particularly for those who appear to be fulfilling the neoliberal ideal of enterprise growth: entrepreneuremployers. Therefore, conducting studies with entrepreneurs in economically developed, everyday contexts is seemingly critical in understanding the potential universality of accepted entrepreneuring-as-emancipation perspectives (Rindova et al., 2009).

In the following section, we discuss current understandings of emancipation within organisation and entrepreneurship literatures. Two dominant perspectives, micro and 
macro approaches, are identified (Goss et al., 2011). This polarisation of emancipation has seemingly led to a middle ground in need of further exploration. Thus, we point to ways our research can empirically bridge these two perspectives, contributing to a deeper understanding of emancipation.

\section{Entrepreneurship and Emancipation}

Tracing the concept of emancipation is a complex and challenging endeavour (Lindebaum, 2017). Broadly, the verb 'to emancipate' refers to a setting something, or someone 'free from control' or constraints (Lindebaum, 2017: 3). This immediately draws attention to extensive debates on what exactly 'freedom' is, or why and how it is a necessary state to achieve (Forder, 2019). These debates are far reaching and concern scholars across a wide range of academic disciplines (Peoples, 2020). However, the complexity of emancipation is not always recognised within entrepreneurship literatures (Rindova et al., 2009). Critical work continues to highlight a need to better theorise emancipation within entrepreneurial contexts (Ruebottom and Toubiana, 2020; Verduijn et al., 2014; Alkhaled and Berglund, 2018).

Within organisation studies, broadly two distinctions emerge: macroemancipatory, and micro-emancipatory perspectives. Macro-emancipatory perspectives demand radical transformation of not only the workplace, but also society more generally (Alvesson and Willmott, 1992). This demands that critical social sciences should fundamentally contribute to liberating people from various forms of oppression. For traditional critical theorists, emancipation remains a Kantian universal imperative, not a hypothetical one (Klikauer, 2015, 2018). Critiques of this approach argue that a focus on macro-emancipation tends to ignore many of the fleeting attempts to create limited zones of freedom (Huault et al., 2014). Alvesson and Willmott (1992: 446) labelled macroemancipation as 'orthodox' and 'grandiose', preferring to focus instead on 'microemancipation'.

This perspective highlights 'concrete activities, forms, and techniques that offer themselves not only as means of control, but also as objects and facilitators of resistance and thus, vehicles for liberation' (Alvesson and Willmott, 1992: 446). In this formulation, processes of emancipation are understood to be 'uncertain, contradictory, ambiguous, and precarious' (Alvesson and Willmott, 1992: 446). Nevertheless, there are three problems 
associated with a micro-approach. First, researchers appear to privilege minor acts of micro-emancipatory resistance (Goss et al., 2011). Second, a narrow focus on microemancipation may encourage researchers to omit broader consequences of everyday behaviours and context. Thirdly, a micro-approach may unintentionally create an unhelpful, and rather artificial, separation between macro and micro struggles.

The division of micro and macro approaches creates a tension between social and economic emancipation exposing an artificial separation between wider structures (social, political, economic) and individuals that operate within them. Consequently, the complex dynamics that underlie or connect such struggles may be lost (Spicer and Böhm, 2007). In this vein, we identify a need to bridge micro and macro perspectives to understand fully the extent to which entrepreneurs experience emancipation. We are not alone in this conclusion, Huault et al., (2014) turn to the works of Rancière (2009) to develop such a bridge by examining the worker in organisational life. Rancière conceptualises emancipation as the attempt to 'actualise equality' (Rancière, 2009: 509), and that emancipatory practices seek to bring about dissensus. For Rancière, what the dominated do not need is their exploitation revealed to them by intellectual experts. Rather, what is required is a vision of themselves beyond a world of exploitation. This explicitly challenges the assumption, held by both macro and micro accounts of emancipation, that 'knowing the system' is a pre-requisite to achieving liberation (Huault et al., 2014: 10).

Whilst broader literature on emancipation can be largely discerned across a macro or micro level of analysis, with some attempt to consider the 'mid-ground', literature that has focused on emancipation in the context of entrepreneurship has tended to presume that the emancipatory potential of entrepreneurship emerges through neoliberal notions of individualism, responsibility, agency and achievement (Bröckling, 2016). Implicit is the belief that entrepreneurship is 'liberating and meritocratic', and thus 'desirable and accessible to all' (Martinez Dy et al., 2018: 587). This notion of emancipatory potential has been particularly encouraged by the work of Rindova et al. (2009). The authors introduced the concept of entrepreneuring-as-emancipation to 'broaden the focus of entrepreneurship research' (p. 478). The authors suggest that engagements with entrepreneurship are viewed through an emancipatory lens (Alkhaled and Berglund, 2018), and therefore employ a macro emancipatory interpretation of entrepreneurship (Rindova et al., 2009). Relatedly, many other investigations also build on this kind of implicit 
assumption as to the emancipatory potential of entrepreneurship (Ruebottom and Toubiana, 2020; Nikolova, 2019; Shir et al., 2019; Verme, 2009). Consequently, the potential for entrepreneuring-as-emancipation remains a dominant perspective within this area of research.

Nevertheless, there are a small number of empirical studies that have explored and challenged Rindova et al.'s (2009) conception, such as Jennings et al. (2016), Alkhaled and Berglund (2018), and Goss et al. (2011). Drawing on micro-emancipatory perspectives, this type research assumes that the entrepreneur is implicitly seeking some form of emancipation from something. It suggests that a disjunction exists between an entrepreneurial fantasy and the realities experienced by entrepreneurs. In seeking to explain and understand freedom, oppression or resistance, reductive approaches (Jennings et al., 2016; Petergova et al., 2017) do not always provide multi-agent or multi-level analysis. Rather, such approaches tend to focus on what is local, immediate or measurable, resulting in 'thin' descriptions and weak explanations (Brannan et al., 2017; O’Mahoney et al., 2018).

Therefore, as with the broader literature on the subject, research that explores entrepreneurship and emancipation struggles to bridge between macro and micro perspectives. This difficulty is evident in Laclau's (1996) conceptualisation of emancipation that rejects the possibility of formulating a universal identity, along with any project uniting a world under a single banner of rationality. Instead, Laclau (1996) suggests the relationship between the universal and particular is a pseudo-marriage: they cannot live with each other and cannot live without each other; 'universality is incommensurable with any particularity but cannot, however, exist apart from the particular' (p. 34).

Consequently, those that have so far pursued a 'mid-ground' such as Huault et al. (2014) are still left without the detail of what participant visions of emancipation (or equality) are, or how they make sense of them beyond the bounds of organisational life. For example, what if their visions are influenced by contemporary entrepreneurial discourses (i.e. being your own boss) that imply leaving an organisation and becoming an entrepreneur leads to an emancipatory state? Progress is made by Martinez Dy et al. (2018) and Cook (2020), who highlight that greater accessibility to enterprise through the use of digital platforms does not facilitate liberation from wider structural and cultural influences 
and/or inequalities. However, there remains a notable gap; a lack of conceptual focus on emancipation and if or to what extent it is subjectively experienced by entrepreneurs. In particular we note a lack of existing empirical work to understand the transition from entrepreneur to entrepreneur-employer, and to what extent emancipation is experienced during this stage in the entrepreneurial process.

Here we highlight Verduijn et al.'s, (2014) use of Laclau's emancipatory perspective as a significant attempt to move beyond what is deemed an untenable dichotomy. Verduijn et al. (2014: 100) provide a conceptual solution by introducing an 'as-well-as position', contending that 'emancipation and oppression are immanent potentials of entrepreneurship'. This conception shifts attention towards what and indeed, how entrepreneurial experiences impact the potential to be emancipated or oppressed. In support of this position, Alkhaled and Berglund (2018: 896) conclude that the notion of 'entrepreneurship as social change' is a 'two-headed phenomenon, comprising emancipation and oppression as forces that stand in a relationship of constant tension'.

To extend the work of Alkhaled and Berglund (2018), we adopt this understanding of emancipation when exploring to what extent it is experienced by entrepreneurs when transitioning from entrepreneur to entrepreneur-employer. For individuals that practice entrepreneurship by owning a venture, their entrepreneurial selves become shaped by neoliberal and entrepreneurial discourses that map out how the entrepreneur can seek success (Dardot and Laval, 2019). Logics of business are readily used to promote enterprise-growth as a vehicle for not only achieving personal and economic success, but also helping to fix issues such as high unemployment (European Commission, 2020; OECD, 2019). Growing an enterprise and becoming an entrepreneur-employer can perhaps be regarded as a significant achievement in becoming the ideal neoliberal subject. In fulfilling this aim emancipation can be realised, as envisaged by entrepreneuring-asemancipation literatures (Rindova et al., 2009). However, as noted by Verduijn et al. (2014) and Alkhaled and Berglund (2018), a duality between oppression and emancipation are always present. Thus, more nuanced accounts of how emancipation is experienced by those seeking to fulfil their entrepreneurial ideals are needed. The following section outlines our methodological choices. In doing so we suggest a phenomenological framework to explore the often-neglected middle ground between micro and macro emancipatory research approaches. 


\section{Methodology}

We draw on the principles of IPA developed by Smith and colleagues $(1996 ; 2012)$ to inform both research design and analysis. In response, our research takes a phenomenological position. Phenomenology seeks to capture more fully the richness of individuals lived experiences (Berglund, 2015). Phenomenological approaches are gaining momentum within the entrepreneurship domain (Raco and Tanod, 2014; Berglund, 2015). One approach, Interpretative Phenomenological Analysis (IPA) (Smith, 1996) has been used to explore entrepreneurial learning from failure (Cope, 2005; Mandl et al., 2016), entrepreneurial leadership (Kempster and Cope, 2010; Lewis, 2015), performance (Tasnim et al., 2014), sustainability (Munoz and Cohen, 2018) and embeddedness (McKeever et al., 2015). One of the significant features of IPA is a commitment to retain the rich and personal detail of the particular, whilst pointing to ways in which the particular illuminate characteristics of a lifeworld that are common to us all (Eatough and Shaw, 2019). Consequently, we believe this methodology provides a useful framework to bridge micro and macro emancipatory perspectives.

Three theoretical principles form the foundation of an IPA approach. Firstly, in taking a phenomenological position, it adopts an 'expressivist ontological' (Eatough and Smith, 2017) stance stemming from its commitment to the examination of how people make sense of major life experiences (Smith, 2019). Therefore, in our research the entrepreneur is regarded as the 'experiential authority' (Yanchar, 2015). Secondly, IPA is idiographic and therefore committed to the examination of each unique, particular experience of participants (Eatough and Smith, 2017). Thirdly, IPA is in line with the interpretative (hermeneutic) tradition rather than the descriptive tradition within phenomenology (Smith et al., 2012). This is implicit in the concept of double hermeneutics: the participants try to make sense of an experience (the first hermeneutic layer), upon which the researcher then makes his/her own interpretation (the second layer). Smith et al. (2012) stress that the purpose of IPA is an attempt to gain an insider perspective of the phenomenon being studied, whilst acknowledging that the researcher is the primary analytical instrument. Herein, researchers' beliefs are not seen as biases to be eliminated, but rather are necessary for making sense of the experiences of other individuals.

The use of creative and visual methods within IPA research is gaining traction. IPA studies on other topics using photo-elicitation (Silver and Farrants 2016), visual voice 
(Williamson, 2018), and found images (Bacon et al., 2017) demonstrate the utility of this approach. Within entrepreneurship, gender studies make effective use of visual methods (Pritchard et al., 2019; Swan, 2017; Duffy and Hund, 2015; Swail et al., 2014; Smith, 2014). There are also promising methodological developments utilising visual and creative methods to understand entrepreneurial identities (Clarke and Holt, 2019). The importance of metaphors in theorizing entrepreneurship has also been considered (Lundmark and Krzeminska, 2019; Welter, 2019). Perhaps the work that most closely resembles our own is that of Clarke and Holt (2019), who use drawing to explore entrepreneurial experiences. Notable parallels can also be drawn from Berglund and Wigren-Kristoferson's (2012: 280) use of pictures and artefacts as stimuli for critical reflection and 'co-produced empirical material'. Indeed, within entrepreneurship research visual, creative or multi-modal approaches are gathering momentum as useful methods to examine nuanced and complex entrepreneurial experiences (Clarke and Holt, 2019; Wiklund et al., 2019).

Critiques have highlighted that, akin to other phenomenological methods, IPA does not always acknowledge the integral role of language within the processes of data collection via interview (Willig, 2013). This raises questions on whether IPA can accurately capture meanings of experiences rather than just opinions of them. In particular accessing an individual's world in sufficient depth requires participants and researchers to possess the requisite linguistic skills to communicate the nuances of an experience. More generally it implies phenomenological methods may only be effective with the most articulate individuals (Willig, 2013). Such criticism could be discriminatory, suggesting only those with certain levels of fluency are able to describe their experiences.

Building on both these developments visual and creative methods have been increasing used to overcome the reliance on linguistic fluency to communicate meaning (Boden et al., 2019; Zielke, 2019). Encouraged by this, we conducted object-interviews using Lego (see Fig. 1). Our use of Lego was inspired by the work of Gauntlet (2007), who adopted the Lego Serious Play methodology as a social research tool, now used across a range of academic disciplines (Rainford, 2020; McCusker, 2020; Wengel and McIntosh, 2019). Visuality and materiality are regarded as distinct modes of constructing and communicating meaning (Jones et al., 2017). Although there is some criticism that the visual and the verbal modes substitute for one another (Gehman and Grimes, 2017), most 
research points to complementary, mutually reinforcing roles (Boxenbaum et al., 2018; Cartel et al., 2018).

A small, purposive, homogenous sample was used, in accordance with IPA principles, which prioritises the case-level depth or richness within a dataset (Smith et al., 2009). Six business owners based in South Wales, who had all employed their first employee within the past six years, were recruited using both researcher networks and snowball sampling strategies. Participants were based in rural and urban areas and worked in a variety of industries. The sample includes three males and three females (see Table 1 and Fig. 2). All participants provided informed consent.

To start the interview, we asked participants to build and name their selves in Lego as a familiarisation exercise. Their chosen names became their pseudonyms (see Fig. 2) and are used throughout this article. Following this, we used an 'interview arc' format consisting of a 'build-talk-build-talk' to structure the interview encounter (Boden et al., 2019). Participant's Lego constructions provide an interesting starting point to elicit verbal data and encourages participants to flesh out their comments. To do so, the interviewer can enquire into position, colour or form by making simple observation statements, which are typically enough to elicit more detail from the participants. After the approach was successfully piloted, the first author conducted all the interviews. Interviews were unstructured and conversational in nature - the experience of starting their ventures and hiring initial employees was used as the temporal focus. Prompting questions were kept open and narratives were directed by participants. The notion of 'emancipation' or 'freedom' was not addressed directly, but was a common feature across all accounts, and was therefore investigated further at the point of analysis. 


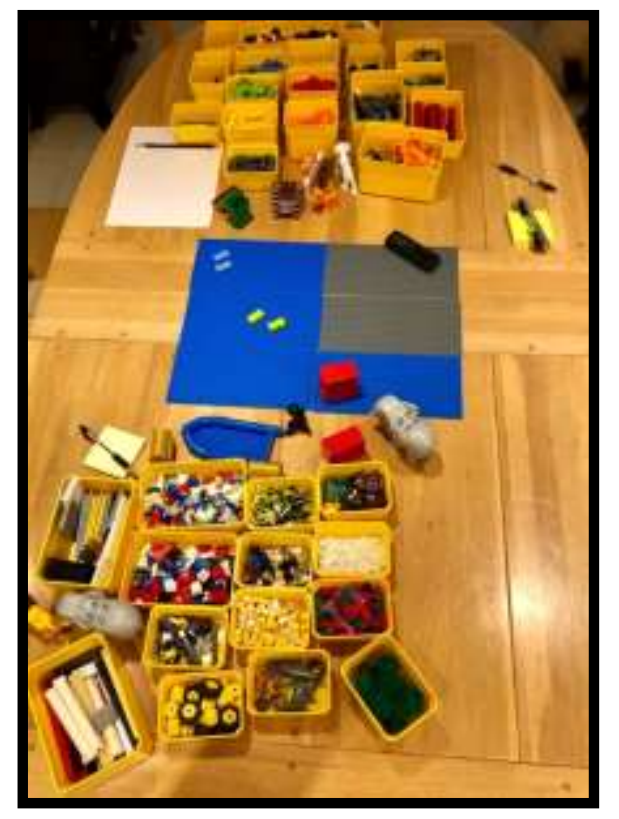

Figure ${ }^{1}$. Using Lego in an interview

IPA is systematic in its analytical procedures. Coding and thematising in IPA are based on a set of underlying principles (Smith et al., 2009) that involve: (1) movement from the descriptive to the more explicitly interpretative (coding); (2) moving from the specific to the thematic; and (3), from the case to the wider sample (identifying convergent and divergent themes). While there is a broadly outlined process to IPA (moving from the descriptive to the interpretative), the method does not 'claim objectivity through the use of a detailed, formulaic procedure' (Brocki and Waerden, 2006: 97).

Interviews were anonymised at the point of transcription. Following this, each transcript was analysed and coded line by line to note the experiential concerns of each participant (Larkin, 2015). Themes were identified through exploring patterns of meaning associated with these concerns. Once themes were developed for each transcript, a cross-case analysis identified one superordinate theme, 'A never-ending story', comprising two sub-themes.

\section{Table 1. Participant Characteristics}




\begin{tabular}{ccccccc}
\hline Pseudonym & Industry & Employees & $\begin{array}{c}\text { Age of } \\
\text { Venture }\end{array}$ & $\begin{array}{c}\text { Years open } \\
\text { until first } \\
\text { hire }\end{array}$ & Age & Gender \\
\hline Phoenix & Service & 10 & 6 & 0 & $25-35$ & Male \\
Melissa & Service & 1 & 5 & 2 & $25-35$ & Female \\
Bish & Agriculture & 3 & 4 & 0 & $25-35$ & Male \\
Alex & Leisure & 30 & 6 & 0.5 & $35-45$ & Female \\
Max & Manufacturing & 5 & 5 & 1 & $35-45$ & Male \\
Bobbie & Technology & 2 & 2 & 1 & $35-45$ & Female \\
\hline
\end{tabular}

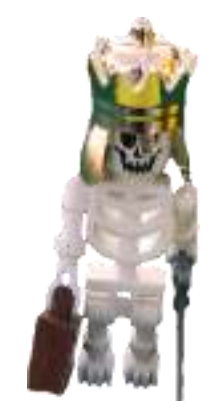

Phoenix

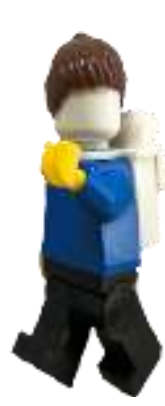

Melissa

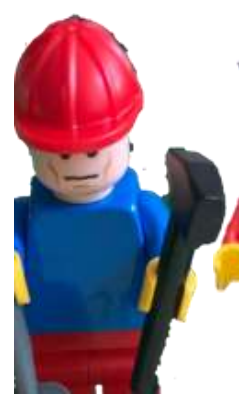

Bish

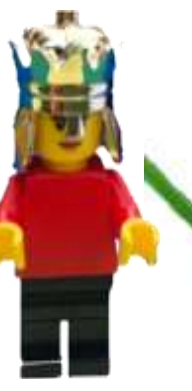

Alex

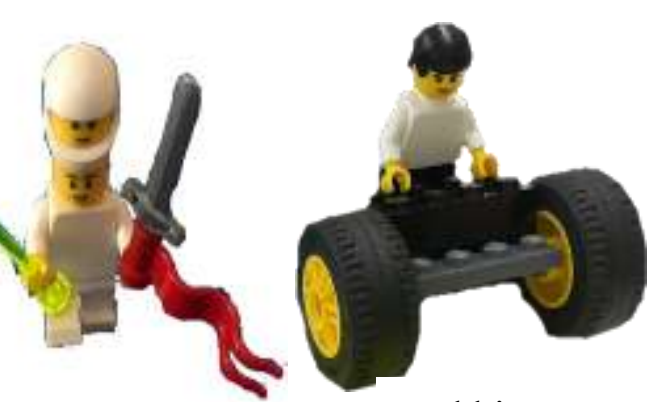

$\operatorname{Max}$

Bobbie

Figure 2. Participant's Lego models of themselves

In the following section, findings are presented as an interpretative phenomenological narrative to explicate both the process and content dimensions of our participants experiences as feelings of control, freedom and entrapment. In keeping with IPA's principles, theoretical assumptions are suspended and addressed in the discussion section.

\section{Findings}

In addressing our research question (to what extent do entrepreneurs experience emancipation when transitioning from entrepreneur to entrepreneur-employer?) we present 
Climbing to freedom on an impossible staircase

findings related to the superordinate theme, A never-ending story, comprising two experiential sub-themes: 'But, it's my decision' and, 'The staircase you keep climbing, but never reach the top'. To begin, the first subtheme traces initial feelings of emancipation, often present when discussing the decision to start their enterprises. However, as the second subtheme reveals, as participants began to reflect on their experiences of becoming an employer, the transition introduced new and unexpected levels of constraint. As such these findings capture participant's becoming increasingly aware that as entrepreneuremployers, achieving entrepreneurial ideals such as autonomy, freedom or wealth may not ever be fully realised.

The themes explored speak to the transience of selfhood and relationality. These lifeworld aspects do not exist discretely; rather, they are connected within the narratives of each participant. Such narratives encompass the totality of each participant's entrepreneurial endeavours. Furthermore, our analysis explores common transitional touchpoints, namely the decision to start a business and the relational aspects of employing staff (Boden et al., 2019).

\section{A Never-ending Story}

Our overarching theme captures what we interpreted as common when transitioning to an entrepreneur-employer. Upon becoming an entrepreneur-employer, initial emancipatory feelings experienced as an entrepreneur are replaced with ones of frustration. Participants' narratives reflected a continuous loop of ascending and descending emotions; a collection of never-ending stories often revealing fleeting glimpses of freedom, before being overwhelmed by existing constraints. As Phoenix explained, 'It's like I'm chasing it all the time. I'm chasing... there is no pot at the end of the rainbow'. We were reminded of the work of Penrose and Penrose (1958), who's depiction of a two-dimensional staircase was termed the 'impossible stairs'. The stairs make four 90-degree turns as they ascend or descend forming a continuous loop, such that a person could climb them forever and never get any higher.

This defeats our known purpose for a set of stairs, namely, to get you to an end point above or below to where you started. Thus, the 'impossible staircase' defeats any notion of overall progress and is itself, never-ending. Phoenix's experience of 'constantly 
chasing' was reflected and shared by others. Consequently, a gap between entrepreneurial discourse 'the pot at the end of the rainbow', and participants' entrepreneurial realities emerged, revealing 'a never-ending story' of chasing an entrepreneurial freedom that is never realised.

However, analytically we identified glimpses of emancipation within the narratives of the six participants. On the staircase you are free to execute certain decisions; whether to get on, which way to turn, or whether to get off. It is in these decisions we found fleeting moments of freedom. For our participants, these were transitional touchpoints where the autonomous-self became salient. We will explore these ideas in more depth through our first sub-theme, 'But, it's my decision'.

\section{'But, it's My Decision'}

For Bobbie, Bish and Melissa the decision to start their own business provided a lens for their interpretation of freedom. In Bobbie's explanation below, she describes her actions as an autonomous rejection of her past 'corporate life';

Freedom. So, there's a real thing about freedom for me. Yes, and this is probably a reaction to kind of, past, rather than a driver for now... I'm probably working harder than I've ever worked before, I'm certainly getting up earlier than I was when I was in corporate life. But, it's my decision.

In othering her past self, Bobbie's recognition of 'freedom' as not a 'driver for now' evokes a temporality to her feeling of freedom. This suggests that there is a constant throughout Bobbie's narrative; continual references to a 'corporate world', 'corporate slog' highlight how Bobbie may separate what she feels are two distinct selfhoods. The listing of what she can do now, compared to her past life, perhaps provides a tangible measure of the meaning of freedom for Bobbie and perhaps within this shift emancipation was experienced.

Such a distinct separation between past and present was not initially existent in Bish's account. Instead, impressions of being 'free' were situated within specific moments in his past: 
Climbing to freedom on an impossible staircase

I used to, on the way to school I remember this quite clearly, I used to see bin-men, anyone like that, postman, anyone and I remember thinking they were sort of free, whereas I was stuck in school. (Bish)

For Bish, his initial take on freedom was linked to where his work was, not what or with who. The commonality amongst these two participants was their focus on this transition as a deliberate act for themselves.

Like Bobbie, Alex distinguished between her past and present through presenting different forms of work worlds. Both sought freedom in their decision to move from being employed to being self-employed and were careful to distinguish between past and present selves. For Alex, the feeling of being able to be 'different' was illuminated through her continual comparison of her business to the 'corporate structure' of other businesses.

This is my business [on the left]. It's a bit more mismatched and colourful... But, the corporate structure [on the right] just it's basic it's got everything on there that we've got but less fun and you could probably replicate like a McDonald's pod. You know it could be anywhere, you could be anywhere and do it. Mine is definitely quirky.

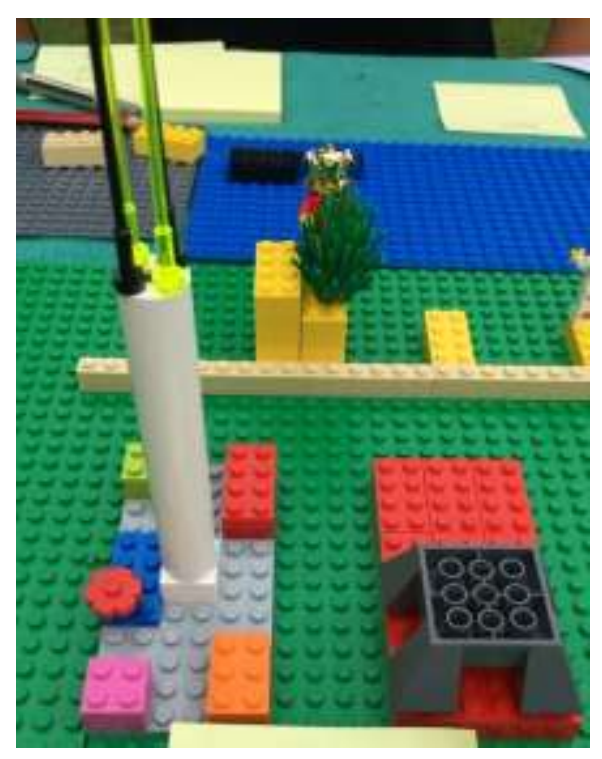


Figure 3. Corporate vs. Quirky (Alex)

Alex's use of 'quirky', 'colourful', 'mis-matched' to describe her business may represent how she wishes her business to be perceived. It alludes to entrepreneurial discourses that construct entrepreneurial ventures as rebellious and 'innovative', perhaps representing her 'pot of gold'. A juxtaposition between perception and reality emerged when exploring how her business became a means of control when her father died very suddenly.

I don't like being out of control in any way, in any part of my life... I'm not a complete control freak either. I like to just feel, it makes me feel safe I suppose and if everything is pretty much ordered it's all good...Well in work wise, decisions like I suppose setting policies and procedures so that there is consistency helped... But generally, I think people as a human race we feel safer knowing what's happening.

Alex's narrative twists and turns through contradictions; declaring not liking being out of 'control in any way' was quickly followed with stating that she's not a 'complete control freak'. There is a sense that Alex is continually navigating between expectations and her reality. When probed further, despite building a model to represent difference and disorder, the reality was a need to restore order to satiate her need for feeling in control. Within her business, she implies that this was through her 'decision' to implement policy and procedures, many of which imitate the very corporate structures she wished to differentiate herself from. In this instance, such decisions provided momentary periods of control for Alex, emancipating her from a level of disorder becoming an employer introduced.

Interpreting this further, conflicts within these decisions appeared when participants began to talk through the day-to-day aspects of entrepreneurial activities. Participants' stories began to reflect a constant tension between the entrepreneurial ideal and the reality of keeping their business going in their contexts. For Bish and Max, who rely on a regular customer base for venture survival, the reality between their ideal entrepreneurial world and the one they have to inhabit began to surface. 
...it's not always people that cause the tension... It can be the things I want- so like, I want the business to do well, but I don't want to do jobs that are bad for the environment. Sometimes we get offered jobs that in my opinion, you know, shouldn't be happening... But the conflict then is, right, what have we got - have we got enough work for me to say no, or not? So sometimes it's, 'all right we'll do it anyway'... It's tricky. But I am happy.

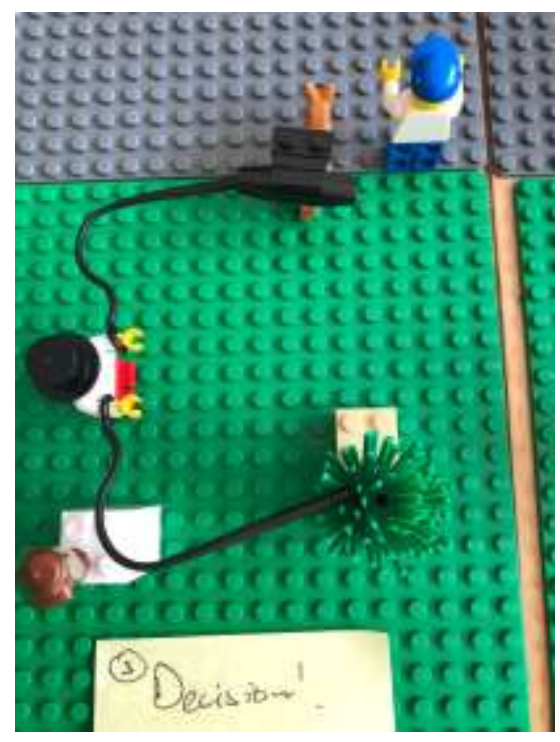

Figure 4. Decision! (Bish)

The tension described expresses a struggle between what he considers ethical, and what is necessary for his business to survive. Yet, despite the inability to be fully autonomous and satisfy his ethical beliefs, a declaration of happiness is made. This suggests the level of self-autonomy provided by his business is enough to provoke feelings of joy and thus could be considered as emancipatory. The conflict Bish experiences highlights wider contextual constraints which are nominally universal. For a business to survive it requires money, which requires a regular delivery of a service or goods. For Max, this fundamental aspect of survival took its toll in the initial years of starting his business:

To be honest it was just about keeping everything afloat, just surviving like. Yeah at Christmas time, crikey, I decided... I stopped for a Christmas break and I just went boof, getting flu and 
everything, it's like my body just shut down and I just crashed... I wanted to burn the place after that. But you know it taught me my limits.

Max's experience of an embodied constraint demonstrates the limits his own body put upon him in his pursuit of his need to survive. It humanises the entrepreneurial endeavour as one that is not only constrained by universal structures, but also by our own limits as living beings. The suggestion here is that for Max, achieving emancipation is only possible through the maximising of personal effort, but such an effort is bounded by his own physical limitations.

How do feelings of freedom surface through an apparent continuum of constraint? We suggest that it is in the making of often fleeting decisions during which participant realities are suspended is where emancipation is readily felt. At these times, some appear to be caught up in a moment that can produce a kind of euphoria - even a sense of adequacy or fullness - that temporarily eclipses the anxiety endemic to a critical awareness of their world's tragic complexity. Bish and Melissa demonstrate how fleeting emancipatory moments were significant in that they executed choice and deliberate acts to change in their lives. Max and Alex's decisions connected notions of embodiment and selfhood, a reminder that our own selves can act as a significant constraint. Conversely, both Max and Alex found ways to mitigate the constraint through exercising acts of selfcontrol. Finally, for Bobbie, despite their temporality, these moments of choice provide sufficient meaning to find and fulfil her lost selfhood, declaring: 'I think I've become me again'.

In our second sub-theme, we return to the concept of the impossible staircase. We will explore constraints which are beyond participants perceived control, and how the fragility of their original notions of freedom became salient through the relationality of becoming an employer.

\section{'A staircase you keep climbing, but never reach the top of'}

We found that participants experiences revealed relationality as intimately bound to a growing awareness of oppressive forces developing within their worlds. This awareness became salient when discussing participants experiences of hiring and managing their 
employees. Earlier references to forms of emancipation were lost to feelings of entrapment, tension, frustration and confusion.

Melissa, who employs one member of staff, found the experience of dealing with her employee highly constraining. To cope with the growth of customers, Melissa hired a friend in need of work. In the extract below, Melissa navigates between feelings of frustration caused by structures outside her control and being trapped by her decision to hire her friend.

Like, having an employee and like, paying their holiday pay and things is really difficult, because you have to pay them the full amount while the business is taking essentially half... You know I cannot take holiday... So, it's really difficult. It's hard to take any time off... There's no help.

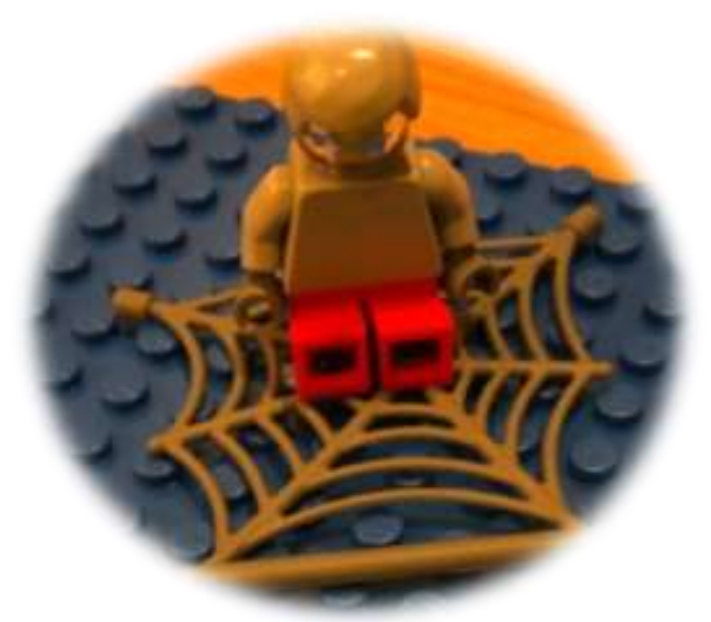

Figure 5. Trapped: a victim of my own success (Melissa)

...I was trapped basically, and locked in with my own success I think... And, eventually it got to the point where I was becoming quite ill like, physically.

The influential constraints that guide Melissa's actions began to surface in her description of managing her employee. Beyond the relational difficulties of managing her friend, 
Melissa highlights a constant state of tension between her business needs and her own. It illuminates the impact of legislative structures beyond Melissa's control. Growth of her customer base meant she employed a staff member, which many discourses construct as a measure of success. The impact of that success is that the cost of having an employee is both personal and financial; the staircase begins to form and oppress.

Max alludes to this 'trap' in his own narrative. Having experienced a surge in orders he hired a family friend to be able to meet the needs of his business. Highlighting a tension between maintaining levels of production and training (Baumeler and Lamamra, 2019), Max regarded this as having an impact on him and his enterprise:

It was hard, because you are trying to deal, like run the business as well, train somebody and then obviously mistakes were getting made... it started costing money as well and everything and I was like, oh I cannot afford to do this...

For Alex, her need for control framed her experiences with employees in her business:

...we needed to employ more people but I was a little bit hesitant... And oh god I didn't want to have all the stress of payroll, and you know all the unknowns. I remember opening day, just sat there thinking... 'oh god will they turn up for work?' You know, if they don't then I'm screwed. You're completely dependent on them.

Alex's reference to the 'unknowns echoes a desire to feel in control', conflicting with the needs of her business. It elucidates a relational instability between herself and her employees, compounded perhaps by her need for consistency. The 'dependency' she felt was significant in our understanding of this relational dynamic. Consequently, we noted such feelings may have resulted in a shift in the locus of control (Lefcourt, 2014), at the point Alex transitioned from entrepreneur to entrepreneur-employer. 
Wider constraints outside our participants control were also apparent in Phoenix's narrative. The battle between Phoenix's vision for what he desired his business to be 'a legacy', was at times experienced as a matter of frustration for him. '...If I was to go VAT registered here, I'd be shut with six months. And that's the government doing that to me. It's a constant battle'.

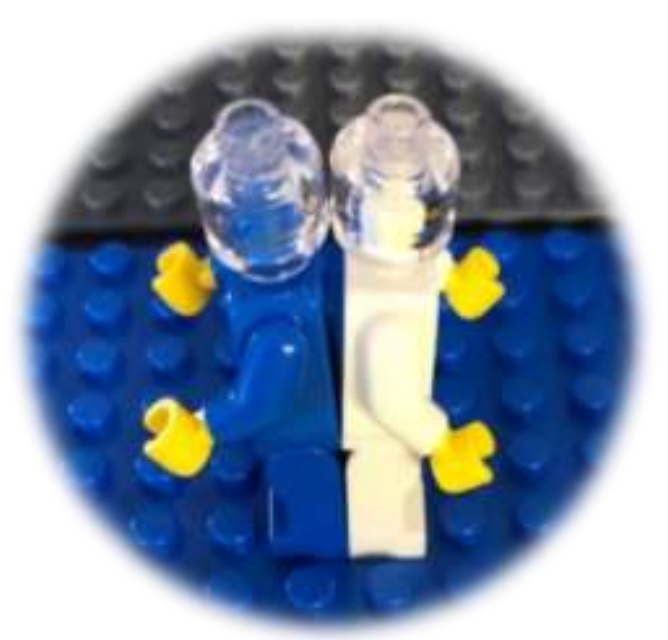

Figure 6. A Battle (Phoenix)

Phoenix referenced this constant battle with constraints, like employment regulations, throughout his account. His use of language evokes notions of unfairness and oppression: 'that's the government doing that to me', suggests feelings of being singled out by an institution which is beyond his control that impacts his ability to achieve his entrepreneurial goals. Perhaps because of this the metaphor of the impossible stairs was one that he frequently returned to. Phoenix's analogy provided us with the basis for the wider conceptualisation of participants experiences of emancipation. His frustration was perhaps grounded by a disjunction between his expectations of entrepreneurial success, which for him, were rapidly becoming unobtainable when confronted with the realities of running his business.

Okay, do you know what... do you remember the film Labyrinth? Know the bit where she is going up the stairs and falling back down 
and she never gets to the top? I don't understand how people do make money, I really don't.

The 'top' for Phoenix could relate to his interpretations of success, he noted throughout our discussion he had read a number of entrepreneurs' autobiographies noting a number of heroes. We suggest that his ideas of success are influenced by an entrepreneurial discourse that idealises success as a 'pot of gold at the end of the rainbow' (Anderson and Warren, 2011; Johnsen and Sørensen, 2017). Consequently, his frustration and questioning of these ideals discloses an awakening to constraints apparent within his lifeworld.

Finally, we return to Bobbie, whose initial feelings of liberation were born out of leaving another world she rejected. What struck us with her story, was through the interview, her reflections provoked her to connect between her past feeling of liberation and present realities.

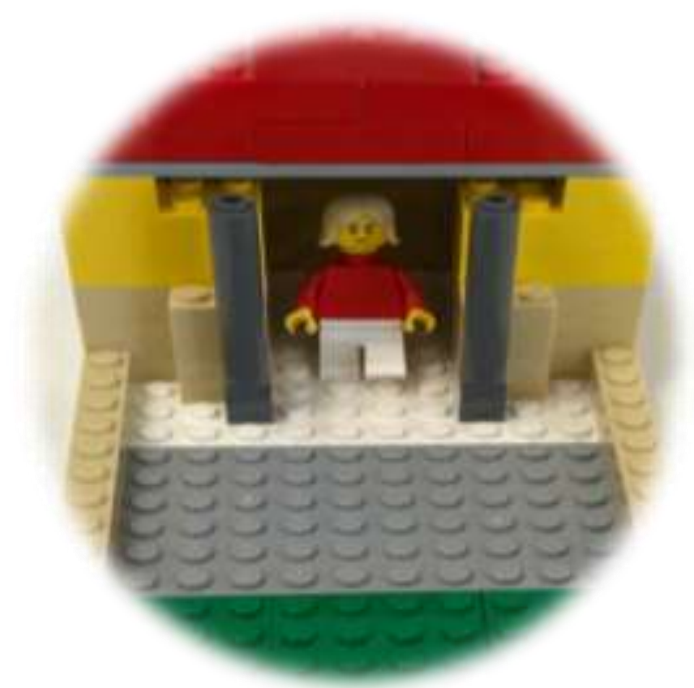

Figure 7. Stuck in an ugly corporate world (again!) (Bobbie)

\begin{abstract}
Gosh sometimes... you know, I left the corporate world to do what I wanted [laughs]. I thought I'd left that world... [pauses]. But really, it's just the same except this time, it's all on me... Pensions, pay, stress, people, you know. Bloody hell! Not great that is it.
\end{abstract}

Bobbie's reflexive account demonstrates her change in perspective. A realisation that two worlds she thought were distinct, are instead full of similarities. It appears that a key 
difference in how Bobbie makes sense of her entrepreneurial endeavours is through the responsibility she feels towards her employees. Whereas at the beginning, the level of autonomy she sought was framed very much as a positive change, the impact of having staff signals a significant shift in her perspective.

The lived experiences of Bobbie, Max, Phoenix, Melissa, Bish and Alex reveal a constancy of constraint with momentary flashes of freedom. We interpret the transition to employer as significant in participants becoming increasingly conscious of ever-present constraints. As these constraints reveal themselves within their worlds, a battle ensues between various perceived entrepreneurial ideals and their realities.

\section{Discussion}

The study sought to use the lived experiences of entrepreneurs transitioning to entrepreneur-employers to empirically explore the extent to which participants experienced this transition as emancipatory. Here we discuss how our findings subsequently contribute to the literature on entrepreneurship, emancipation, and neoliberalism. Specifically, we consider if entrepreneuring-as-emancipation is realised, or to what extent a tension exists between emancipation and oppression as suggested by the literature (Verduijn et al., 2014). Ultimately, our findings exposed a 'Catch-22' (Heller, 1961) of entrepreneuring-as-emancipation as a situation from which an individual cannot escape because of contradictory rules or limitations. We contribute to critical work on entrepreneurship by demonstrating that whilst there is some potential for emancipation, entrepreneuring-as-emancipation is never fully realised, particularly for the entrepreneuremployer. Instead, as shown in the reflexive accounts of our participants, in becoming entrepreneur-employers a constant tension between emancipation and oppression is experienced.

Our research findings exposed experiential tensions that support Laclau's (1996) conception of emancipation. They demonstrate a plurality of particular emancipations bound within a relational nexus. For example, we interpret micro-emancipatory moments (Alvesson and Wilmott, 1992), revealed in participants choosing to start their ventures, as attempts to pursue entrepreneurial ideologies that form a mechanism of self-affirmation (Rose, 2017). However, as participants begin to reflect on their wider worlds, and in particular on their employees, they are introduced to oppressive structures (Klikauer, 2018) 
that are universally felt. This negative relational effect appears to be complex and multifaceted.

Rindova et al. (2009: 478) argue that if we view entrepreneurial projects as an emancipatory effort then this calls for a focus on 'the factors that cause individuals to seek to disrupt the status quo and change their position on the social order in which they are embedded - and, on occasion, the social order itself'. Such a universal perspective is endemic of neoliberal discourses that privilege entrepreneurship as a 'vehicle of selfrealisation' (Dardot and Laval, 2014: 265). However, in pursuing the neoliberal ideal of growth, moving from entrepreneur to entrepreneur-employer, more constraints are acutely perceived and 'a never-ending story' emerges. Arguably, within a developed economy like the United Kingdom, entrepreneurs can no longer be imagined as radically separable or disruptive. Participants regarded starting their ventures as a means to achieve forms of self-directed change. Bobbie and Melissa left their 'status quo' corporate worlds on this basis, only to imitate them due to the constraints placed upon them by legal structures that lie beyond their control. Such structures encourage particularised perspectives of emancipation and ignore contextual commonalties that suggest larger oppressive forces are at play, limiting the emancipatory potential of entrepreneurship.

Consequently, theoretically, we contribute to an ongoing discussion that questions the emancipatory potential of entrepreneurship. We found that in pursuing the neoliberal ideal of growing their ventures, entrepreneurs operate within structures that they are unable to liberate themselves from. Therefore, we argue the extent to which our participants experience emancipation is partial and temporary at best, particularly once the entrepreneur becomes an employer. This is perhaps a reason for the discomfort that constantly accompanies current emancipatory engagement; this is our, or rather their 'Catch-22'.

The point we emphasise is that, through the lens of Laclau it is impossible to have a fully realised utopian concept of entrepreneuring-as-emancipation (Laclau and Mouffe, 2001). However, the appearance of entrepreneuring-as-emancipation is what we believe to be an essential element to neoliberal subjectification: the power of the imaginary dimension. To understand the influence of neoliberalism is to recognise how it is established and maintained by this dimension, specifically an 'entrepreneurial imaginary' that offers a more desirable way of life (Dardot and Laval, 2019: 65). These imaginaries 
create an illusion of completeness: the possibility of reconciliation between some mythical origin and a future utopian ideal; an ideal that is captured by the notion of 'emancipation'.

In line with other critical literature in this area (Scharff, 2016; Alkhaled and Berglund, 2018; Goss et al., 2011; Gill and Ganesh, 2007; Verduijn et al., 2014; Ahl and Marlow, 2019), participants' narratives revealed glimpses of these imaginaries in their desire to liberate from their past and to relocate their sense of self in an entrepreneurial future that is free and autonomously controlled. Or as the as participant's reflect, to find the 'pot of gold at the end of the rainbow'. Such findings add empirical weight to the notion of the 'entrepreneurial-self'; that an individual's entire existence is annexed by the logic of business (Bröckling, 2016). However, our work goes further to indicate that notions of entrepreneurial ideals of success are also bound by the logics of capitalism that require continued growth. Thus, the 'Catch-22' experience of our entrepreneur-employers suggests a growing crevasse between the discourse and lived realties of entrepreneurial success that in turn, constructs how entrepreneurs perceive failures within a neoliberal context (Olaison and Meier Sørensen, 2014; Gill, 2014).

The findings illustrate the entrepreneur to entrepreneur-employer transition as a double-edged sword, where neoliberal entrepreneurial ideas contrast with the day-to-day realities of being an entrepreneur-employer. This indicates that ideals such as entrepreneuring-as-emancipation (Rindova et al., 2009) are never fully realised. However, it is the endless potential for emancipation that can be seen as a core assumption in neoliberalism, and as the foundations of the entrepreneurial self (Bröckling, 2016). Therefore, becoming an entrepreneur-employer exposes the Catch-22. That is, by fulfilling the implicit assumption that more enterprise growth creates more jobs, paradoxically participants felt less entrepreneurial, and in most cases not like entrepreneurs at all.

Consequently, our research supports the conception of 'entrepreneuring-asemancipation' as a two-headed phenomenon comprising emancipation and oppression as forces (Alkhaled and Berglund, 2018; Verduijn et al. 2014). However, while the two forces are in tension at times, our findings suggest that they are not equal states. We highlight the ephemerality of emancipation, caused by a constancy of perceived constraints. As such, we argue that within a developed neoliberalised context, the transition to employer is a vehicle through which perceived constraints become more readily experienced. We stress that these constraints may lead to the reproduction of the 
status quo within a developed economic context. In addition, we note that the influence of neoliberalism needs to be better understood and accounted for if job-creation through enterprise growth continues to be a key ambition of policymakers.

We have also contributed methodologically to the field of entrepreneurship, enabling exploration of contextually rich empirical data. This was in keeping with IPA's commitment to retaining individual details of the particular, whilst illuminating characteristics of a lifeworld that are common to us all. Studies employing the use of visual methods offer rich empirical work providing insight into how and why such conceptions of entrepreneurial success or intent are constructed (Nadin et al., 2020; Pritchard et al., 2019; Duffy and Hund, 2015; Swail et al., 2014; Smith, 2009, 2010).

Through our methodology, we have added scope to Calás et al.'s (2009) call for more reflexive theoretical analyses and research in critical entrepreneurship studies. While we respond to this call, we also extend that this should be supported by further empirical work. Calás et al. (2009) note that ethical criteria are necessary in judging the consequences of knowledge any field produces, although they stop short of detailing what this should constitute. We are cautious with our claims of emancipatory potential and acknowledge our study is limited by its methodological, temporal and geographical scope.

\section{Conclusion}

Our study contributes to the body of empirical work that seeks to investigate the emancipatory potential of entrepreneurship. We critically challenge the emancipatory potential of entrepreneurship through exploring these concepts in the context of six (female and male) entrepreneur-employers, based in South Wales, UK. Our findings support studies that suggest that potential for emancipation is intimately related to wider contextual constraints experienced by entrepreneurs. More significantly, we found that the transition to employer introduced additional layers of constraint which significantly impacted our participants feelings of freedom and experiences of liberation.

From our findings we believe that the following lessons should be heeded in future research. Firstly, we should engage in investigations with a level of contextual sensitivity that celebrates difference as much as commonality. This means conducting studies in diverse geographic, cultural, economic and social contexts with methods that enable sensitivities to be disclosed. Secondly, understanding the emancipatory potential of 
entrepreneurship at different stages of venture growth may illicit further depth of understanding of the emancipation/oppression continuum (our 'impossible staircase').

Thirdly, in the experiences of our participants, common struggles were shared during the transition to employer. Exposure to structural constraints (maternity pay, tax, payroll) was revealed after employing staff, and was suggestive of a constant oppressive state. We are, therefore, unsurprised by the results of studies (Jennings et al., 2006; Gill and Ganesh, 2007; Jennings et al., 2016) that found entrepreneurs in developed contexts are not likely to enact operating models that depart highly from the status quo. Our participants' micro-emancipatory struggles point to wider constraining structures that are universally common but perhaps more acutely felt by smaller and/or nascent entrepreneurial ventures that could be explored further.

Finally, extant research freely interchanges between the concepts of empowerment with emancipation. Alkhaled and Berglund (2018) argue that the concept of emancipation is weakly or insufficiently conceptualised (Huault et al., 2014). They contend the link between agency and empowerment is misleading and, therefore, problematic (Drydyk 2013). We see this as a potential area for future phenomenological studies to explore, building on the work by Al-Dajani et al. (2015; 2013) and Alkhaled and Berglund (2018) where the focus on emancipation and empowerment provide a lens through which we can begin to understand what is distinct and relational between the concepts.

\section{References}

Ahl H and Marlow S (2019) Exploring the false promise of entrepreneurship through a postfeminist critique of the enterprise policy discourse in Sweden and the UK. Human Relations. doi: 10.1177/0018726719848480.

Al-Dajani H, Akbar H, Carter S and Shaw E (2019) Defying contextual embeddedness: evidence from displaced women entrepreneurs in Jordan. Entrepreneurship and Regional Development 31(3-4): 198-212.

Al-Dajani H, Carter S, Shaw E and Marlow S (2015) Entrepreneurship among the displaced and dispossessed: Exploring the limits of emancipatory entrepreneuring. British Journal of Management 26(4): 713-730. 
Climbing to freedom on an impossible staircase

Alkhaled S and Berglund K (2018) 'And now I'm free': Women's empowerment and emancipation through entrepreneurship in Saudi Arabia and Sweden. Entrepreneurship and Regional Development 30(7-8): 877-900.

Alvesson M and Willmott $\mathrm{H}$ (1992) On the idea of emancipation in management and organization studies. Academy of Management Review 17(3): 432-464.

Anderson AR and Warren L (2011) The entrepreneur as hero and jester: Enacting the entrepreneurial discourse. International Small Business Journal 29(6), 589-609.

Bacon I, McKay EA, Reynolds FR and McIntyre A (2017) 'The Lady of Shalott': insights gained from using visual methods and interviews exploring the lived experience of codependency. Qualitative Methods in Psychology Bulletin, 23.

Baker T and Welter F (2017) Come on out of the ghetto, please! - Building the future of entrepreneurship research. International Journal of Entrepreneurial Behavior and Research 23(2): 170-184.

Baker T and Welter F (2020) Contextualizing Entrepreneurship Theory. London: Routledge.

Bandinelli C (2020) The production of subjectivity in neoliberal culture industries: the case of coworking spaces. International Journal of Cultural Studies 23(1): 3-19.

Baumeler C and Lamamra N (2019) Micro firms matter. How do they deal with the tension between production and training? Journal of Vocational Education \& Training 71(3): 464-481.

Berglund H (2015) Between cognition and discourse: phenomenology and the study of entrepreneurship. International Journal of Entrepreneurial Behaviour and Research 21(3): 472-488.

Berglund K and Wigren-Kristoferson C (2012) Using pictures and artefacts in a PAR process to disclose new wor (1) ds of entrepreneurship. Action Research 10(3): 276-292.

Birch K and Springer S (2019) Peak neoliberalism? Revisiting and rethinking the concept of neoliberalism. ephemera: theory \& politics in organization 19(13): 467-485.

Boden Z, Larkin M and Iyer M (2019) Picturing ourselves in the world: Drawings, interpretative phenomenological analysis and the relational mapping interview. Qualitative Research in Psychology 16(2): 218-236. 
Climbing to freedom on an impossible staircase

Börner S, Petersen N Rosa H and Stiegler A (2020) Paradoxes of late-modern autonomy imperatives: Reconciling individual claims and institutional demands in everyday practice. British Journal of Sociology 71: 236- 252.

Boxenbaum, E, Jones C, Meyer R E and Svejenova S (2018) Towards an Articulation of the Material and Visual Turn in Organization Studies. Organization Studies 39(5-6): 597-616.

Brannan MJ, Fleetwood S, O’Mahoney J and Vincent S (2017) Critical Essay: Metaanalysis: A critical realist critique and alternative. Human Relations 70(1): 11-39.

Brocki JM and Wearden AJ (2006) A critical evaluation of the use of interpretative phenomenological analysis (IPA) in health psychology. Psychology and health 21(1): 87-108.

Bröckling U (2016) The entrepreneurial self: Fabricating a new type of subject. London: Sage.

Brown R, Mawson S and Mason C (2017) Myth-busting and entrepreneurship policy: the case of high growth firms. Entrepreneurship and Regional Development, 29(56): 414-443.

Calás MB, Smircich L and Bourne KL (2009) Extending the Boundaries: Reframing 'Entrepreneurship as Social Change' through Feminist Perspectives. Academy of Management Review 34 (3): 552-569.

Cartel M, Colombero S and Boxenbaum E (2018) Towards a multimodal model of theorization processes. Research in the Sociology of Organizations 54(A): 153180.

Cederström C and Spicer A (2015). The wellness syndrome. London: John Wiley \& Sons.

Chia, R. (2003). From knowledge-creation to the perfecting of action: Tao, Basho and pure experience as the ultimate ground of knowing. Human relations, 56(8), 953-981.

Cook D (2020) The freedom trap: digital nomads and the use of disciplining practices to manage work/leisure boundaries. Information Technology \& Tourism 1-36. https://doi.org/10.1007/s40558-020-00172-4

Cope J (2005) Researching entrepreneurship through phenomenological inquiry: Philosophical and methodological issues. International Small Business Journal 23(2): 163-189. 
Climbing to freedom on an impossible staircase

Dardot P and Laval C (2014) The new way of the world: On neoliberal society. London: Verso.

Dardot P and Laval C (2019) Never Ending Nightmare: How Neoliberalism Dismantles Democracy. London: Verso.

Dean M (2014) Rethinking neoliberalism. Journal of Sociology 50(2): 150-163.

Department for Work \& Pensions (2019) Over 200 businesses started each week through

DWP scheme. Available at: https://www.gov.uk/government/news/over-200businesses-started-each-week-through-dwp-scheme

Department for Business, Energy \& Industrial Strategy (2019) Business Population Estimates for The UK and Regions 2019. Office of National Statistics. Available at:https://assets.publishing.service.gov.uk/government/uploads/system//Business _Population_Estimates_for_the_UK_and_regions_2019_Statistical_Release.pdf

Dey P and Steyaert C (2018) Myth in social entrepreneurship research: an inquiry into rationalist, ideological and dialectic practices of demystification. In: Dey P and Steyaert (eds) Social Entrepreneurship: An Affirmative Critique. Cheltenham, UK: Edward Elgar Publishing, pp. 100-126.

Drydyk J (2013) Empowerment, agency, and power. Journal of Global Ethics 9(3): 249262.

Duffy BE and Hund E (2015) 'Having it all' on social media: Entrepreneurial femininity and self-branding among fashion bloggers. Social Media + Society 1(2): 1-11.

Eatough V and Shaw K (2019) "It's like having an evil twin": an interpretative phenomenological analysis of the lifeworld of a person with Parkinson's disease. Journal of Research in Nursing 24(1-2): 49-58.

Eatough V and Smith JA (2017) Interpretative phenomenological analysis. In: Willig C and Rogers WS (eds) The Sage handbook of qualitative research in psychology. London: Sage Publications, pp. 193 - 200.

Ehrstein Y, Gill R and Littler J (2020) The Affective Life of Neoliberalism: Constructing (Un)reasonableness on Mumsnet. In: Dawes S and Lenormand M (eds) Neoliberalism in Context. Palgrave Macmillan, Cham.

Essers C, Dey P, Tedmanson D and Verduijn K (2017) Critical entrepreneurship studies: a manifesto. In: Essers C, Dey P, Tedmanson D and Verduijn K (eds) Critical 
Climbing to freedom on an impossible staircase

perspectives on entrepreneurship: challenging dominant discourses. Oxford, UK: Taylor and Francis, pp. 1-14.

European Commission (2020) Entrepreneurship Action Plan 2020. Available at: https://ec.europa.eu/growth/smes/supporting-entrepreneurship_en

European Statistical Service (2020) Entrepreneurship Indicator Programme. Available at: https://ec.europa.eu/eurostat/en/web/structural-business$\underline{\text { statistics/entrepreneurship-indicators }}$

Fletcher D and Seldon P (2016) A critical review of critical perspectives in entrepreneurship research. In Landstrom H, Parhankangas A, Fayolle, A, and Riot P (eds) Challenging Entrepreneurship Research, London: Routledge, Chapter 7.

Forder J (2019) Capitalism and Freedom. In: Milton Friedman. Great Thinkers in

Economics. Palgrave Macmillan, London. https://doi.org/10.1057/978-1-137$\underline{38784-4 \_20}$

Fraser N (2017) “Progressive Neoliberalism versus Reactionary Populism: A Hobson's Choice.” In: Geiselberger, H (ed) The Great Regression. Cambridge: Polity Press, pp. $40-48$.

Friedman M (1962) Capitalism and Freedom. University of Chicago Press.

Gehman J and Grimes MD (2017) Hidden badge of honor: How contextual distinctiveness affects category promotion among certified B Corporations. Academy of Management Journal 60: 2294-2320.

Gill R and Ganesh S (2007) Empowerment, constraint, and the entrepreneurial self: A study of white women entrepreneurs. Journal of Applied Communication Research 35(3): 268-293.

Gill R and Scharff C (eds) (2013) New femininities: Postfeminism, neoliberalism and subjectivity. London: Springer.

Goss D, Jones R, Betta M and Latham J (2011) Power as practice: A micro-sociological analysis of the dynamics of emancipatory entrepreneurship. Organization Studies 32(2): 211-229.

Haugh HM and Talwar A (2016) Linking social entrepreneurship and social change: The mediating role of empowerment. Journal of Business Ethics 133(4): 643-658.

Heller J (1999) Catch-22: a novel (Vol. 4). London: Simon and Schuster. 
Climbing to freedom on an impossible staircase

Huault I, Perret V and Spicer A (2014) Beyond macro-and micro-emancipation: Rethinking emancipation in organization studies. Organization 21(1): 22-49.

Husserl E (1962) Ideas: General introduction to phenomenology. New York: Colliers.

Jarrodi H, Byrne J and Bureau S (2019) A political ideology lens on social entrepreneurship motivations. Entrepreneurship and Regional Development 31(7-8): 583-604.

Jennings JE, Jennings PD and Sharifian M (2016) Living the dream? Assessing the 'entrepreneurship as emancipation' perspective in a developed region. Entrepreneurship Theory and Practice 40(1): 81-110.

Johnsen CG and Sørensen BM (2017) Traversing the fantasy of the heroic entrepreneur. International Journal of Entrepreneurial Behavior and Research 23(2): 228-244.

Jones C, Meyer R, Höllerer MA and Jancsary D (2017) The material and visual basis of institutions. In: Greenwood R, Oliver C, Lawrence TB and Meyer RE (eds) The Sage handbook of organizational institutionalism (2nd edition: 621646). London: SAGE Publications.

Jones T and Ram M (2015) Entrepreneurship as ethnic minority liberation. In: Baker T and Welter F (eds) The Routledge companion to entrepreneurship. Oxford: Routledge. pp. $391-405$.

Kempster S and Cope J (2010) Learning to lead in the entrepreneurial context. International Journal of Entrepreneurial Behavior and Research 16(1): 5-34.

Klikauer T (2015) Critical management studies and critical theory: A review. Capital and Class 39(2): 197-220.

Klikauer T (2018) Critical Management as Critique of Management. Critical Sociology 44(4-5): 753-762.

Laclau E (1996) Emancipation(s). Verso, New York, NY.

Laclau E and Mouffe C (2001) Hegemony and Socialist Strategy: Towards a Radical Democratic Politics. London: Verso.

Larkin M (2015) Phenomenological psychology. In: Rohleder P and Lyons A (eds) Qualitative research in clinical and health psychology. Basingstoke, UK: Palgrave Macmillan, pp. 155-174. 
Climbing to freedom on an impossible staircase

Lefcourt HM (2014) Locus of control: Current trends in theory and research. London, UK: Psychology Press.

Lewis KV (2015) Enacting entrepreneurship and leadership: A longitudinal exploration of gendered identity work. Journal of Small Business Management 53(3): 662-682. Lindebaum D (2017) Emancipation through emotion regulation at work. Cheltenham: Edward Elgar Publishing.

Lundmark E, Krzeminska A and Shepherd DA (2019) Images of entrepreneurship: exploring root metaphors and expanding upon them. Entrepreneurship Theory and Practice 43(1): 138-170.

Maîtrot M and Niño-Zarazúa M (2017) Poverty and wellbeing impacts of microfinance: What do we know? (No. 190). World Institute for Development Economic Research (UNU-WIDER).

Mallett O and Wapshott R (2020) A History of Enterprise Policy: Government, Small Business and Entrepreneurship. Routledge.

Marlow S (2020) Gender and entrepreneurship: past achievements and future possibilities. International Journal of Gender and Entrepreneurship 12(1): 3952.

Mandl C, Berger ES and Kuckertz A (2016) Do you plead guilty? Exploring entrepreneurs sensemaking-behavior link after business failure. Journal of Business Venturing Insights 5(C): 9-13.

Martinez Dy A, Martin L and Marlow S (2018) Emancipation through digital entrepreneurship? A critical realist analysis. Organization, 25(5): 585-608.

Mavelli L (2017) Governing the resilience of neoliberalism through biopolitics. European Journal of International Relations 23(3): 489-512.

McCusker S (2020) Everybody's monkey is important: LEGO ${ }^{\circledR}$ Serious Play ${ }^{\circledR}$ as a methodology for enabling equality of voice within diverse groups. International Journal of Research \& Method in Education 43(2): 146-162.

McKeever E, Jack S and Anderson A (2015) Embedded entrepreneurship in the creative re-construction of place. Journal of Business Venturing 30(1): 50-65.

Munoz P and Cohen B (2018) Entrepreneurial narratives in sustainable venturing: beyond people, profit, and planet. Journal of Small Business Management 56: 154-176.

Musílek K, Jamie K and McKie L (2020) Cold winds and warm attachments: Interrogating the personal attachment to neoliberal work and economy. Work, Employment and Society 34(3): 514-525. 
Climbing to freedom on an impossible staircase

Nadin S, Smith R. and Jones S (2020) Heroines of enterprise: Post-recession media representations of women and entrepreneurship in a UK newspaper 20082016. International Small Business Journal. doi: 10.1177/0266242620913209.

Nayak A, Chia R and Canales JI (2020) Noncognitive Microfoundations: Understanding Dynamic Capabilities as Idiosyncractically Refined Sensitivities and Predispositions. Academy of Management Review 45(2): 280-303.

Nikolova M (2019) Switching to self-employment can be good for your health. Journal of Business Venturing 34(4), 664-691.

OECD/European Union (2019) Self-employment and entrepreneurship from unemployment. In: The Missing Entrepreneurs 2019: Policies for Inclusive Entrepreneurship. OECD Publishing, Paris.

O’Mahoney J, Vincent S and Harley B (2018) Realist studies of oppression, emancipation and resistance. Organization 25(5): 575-584.

Olaison L and Meier Sørensen B (2014) The abject of entrepreneurship: failure, fiasco, fraud. International Journal of Entrepreneurial Behavior and Research 20(2): 193-211.

Penrose LS and Penrose R (1958) Impossible objects: A special type of visual illusion. British Journal of Psychology 49(1): 31-33.

Peoples C (2020) Emancipation, power, insecurity: Critical Theory and immanent critique of human security. In (ed) Roach C, Handbook of Critical International Relations. Edward Elgar Publishing.

Pergelova A, Angulo-Ruiz F and Dana LP (2017) Entrepreneurship as change-creation: testing the emancipation perspective and its outcomes. Frontiers of Entrepreneurship Research 37(16): 1.

Pritchard K, MacKenzie Davey K and Cooper H (2019) Aesthetic labouring and the female entrepreneur: 'Entrepreneurship that wouldn't chip your nails'. International Small Business Journal, 37(4), 343-364.

Pryor FL (2010) Capitalism and freedom? Economic Systems 34(1): 91-104.

Raco JR and Tanod RH (2014) The phenomenological method in entrepreneurship. International Journal of Entrepreneurship and Small Business 22(3): 276-285. 
Climbing to freedom on an impossible staircase

Rainford J (2020) Confidence and the effectiveness of creative methods in qualitative interviews with adults. International Journal of Social Research Methodology 23(1): 109-122.

Rancière J (2009) The Emancipated Spectator. London: Verso.

Rindova V, Barry D and Ketchen Jr DJ (2009) Entrepreneuring as emancipation. Academy of management review 34(3): 477-491.

Rose N (1992) Governing the enterprising self. In: Heelas P and Morris P (eds) The Values of the Enterprise Culture: The Moral Debate. London: Routledge.

Rose N (2017) Still 'like birds on the wire'? Freedom after neoliberalism. Economy and Society 46(3-4): 303-323.

Rothschild K (2003) Reflections on an anniversary: Friedman's capitalism and freedom. Journal of Economic Studies 30: 548-557.

Ruebottom, T., \& Toubiana, M. (2020). Constraints and opportunities of stigma: Entrepreneurial emancipation in the sex industry. Academy of Management Journal. https://doi.org/10.5465/amj.2018.1166.

Scharff C (2016) The Psychic Life of Neoliberalism: Mapping the Contours of Entrepreneurial Subjectivity. Theory, Culture \& Society 33(6): 107-122.

Shir N, Nikolaev BN and Wincent J (2019) Entrepreneurship and well-being: The role of psychological autonomy, competence, and relatedness. Journal of Business Venturing 34(5): 105875.

Silver J and Farrants J (2016) 'I once stared at myself in the mirror for eleven hours: exploring mirror gazing in participants with body dysmorphic disorder'. Journal of Health Psychology 21(11): 2647-2657.

Smith JA (1996) Beyond the divide between cognition and discourse: Using interpretative phenomenological analysis in health psychology. Psychology and Health 11: 261271.

Smith JA (2019) Participants and researchers searching for meaning: Conceptual developments for interpretative phenomenological analysis. Qualitative Research in Psychology 16(2): 166-181.

Smith JA and Osborn M (2008) Interpretative phenomenological analysis. In: Smith JA (eds) Qualitative psychology: A practical guide to research methods. London: Sage, pp. 51-80. 
Climbing to freedom on an impossible staircase

Smith JA, Flowers P and Larkin M (2012) Interpretative phenomenological analysis: theory, method, research. London: Sage.

Smith R (2009) The Diva storyline: an alternative social construction of female entrepreneurship. International Journal of Gender and Entrepreneurship, 1(2): 148-163.

Smith R (2010) Masculinity, doxa and the institutionalisation of entrepreneurial identity in the novel Cityboy. International Journal of Gender and Entrepreneurship 2(1): 27-48.

Smith R (2014) Images, forms and presence outside and beyond the pink ghetto. Gender in Management: An International Journal 29(8): 466-486.

Spicer A and Böhm S (2007) Moving management: Theorizing struggles against the hegemony of management. Organization studies 28(11):1667-1698.

Swail J, Down S and Kautonen T (2014) Examining the effect of 'entre-tainment' as a cultural influence on entrepreneurial intentions. International Small Business Journal 32(8): 859-875.

Swan E (2017) Postfeminist stylistics, work femininities and coaching: A multimodal study of a website. Gender, Work \& Organization 24(3): 274-296.

Tasnim R, Yahya S and Zainuddin MN (2014) 'I'm Loving It!' What Makes the Successful Entrepreneur Affectively Committed to Entrepreneurial Performance? Journal of Applied Management and Entrepreneurship 19(2): 27.

Tunberg M and Anderson A R (2020) Growing a small firm; experiences and managing difficult processes. International Entrepreneurship and Management Journal, 119.

Van Burg E, Cornelissen J, Stam W and Jack S (2020) Advancing Qualitative Entrepreneurship Research: Leveraging Methodological Plurality for Achieving Scholarly Impact. Entrepreneurship Theory and Practice. https://doi.org/10.1177/1042258720943051

Verduijn K, Dey P, Tedmanson D and Essers C (2014) Emancipation and/or oppression? Conceptualizing dimensions of criticality in entrepreneurship studies. International Journal of Entrepreneurial Behavior and Research 20(2): 98-107. 
Climbing to freedom on an impossible staircase

Verme P (2009) Happiness, freedom and control. Journal of Economic Behavior \& Organization 71(2): 146-161.

Welter F, Baker T and Wirsching K (2019) Three waves and counting: the rising tide of contextualization in entrepreneurship research. Small Business Economics 52(2): 319-330.

Welter F, Baker T, Audretsch DB and Gartner WB (2017) Everyday Entrepreneurship: A Call for Entrepreneurship Research to Embrace Entrepreneurial Diversity. Entrepreneurship: Theory and Practice 41(3): 311-321.

Welter F (2019) The power of words and images: towards talking about and seeing entrepreneurship and innovation differently. In: Audretsch, DB, Lehmann EE and Link AN (eds) A Research Agenda for Entrepreneurship and Innovation, Cheltenham, UK: Edward Elgar Publishing.

Wengel Y, McIntosh A and Cockburn-Wootten C (2019) A critical consideration of LEGO ${ }^{\circledR}$ SERIOUS PLAY ${ }^{\circledR}$ methodology for tourism studies. Tourism Geographies: 1-23.

Wiklund J, Wright M and Zahra SA (2019) Conquering Relevance: Entrepreneurship Research's Grand Challenge. Entrepreneurship Theory and Practice 43(3): 419436.

Williamson I (2018) 'I am everything but myself': exploring visual voice accounts of single mothers caring for a daughter with Rett syndrome'. Qualitative Research in Psychology 16(4): 566-590.

Willig C (2013) Introducing qualitative research in psychology (3rd ed). Maidenhead, UK: Open University Press.

Yanchar SC (2015) Truth and disclosure in qualitative research: Implications of hermeneutic realism. Qualitative Research in Psychology 12(2): 107-124.

Zielke J (2019) Dwelling: On the design, implementation and analysis of 'Story Houses' as multi-modal research method. Qualitative Research in Psychology 1-27.

\section{Acknowledgements}

We would like to thank the Editor for their continued support and expert guidance throughout the review process. In addition, we would like to extend our thanks to the two 
Climbing to freedom on an impossible staircase

anonymous reviewers, whose feedback and insight have greatly strengthened this article's contribution as a result.

\section{Notes:}

${ }^{1}$ All images provided are copyright $($ C Helen C Williams, 2020; permission must be sought before images are reproduced. 